começo do ano, mostram como a rede social se aproveitou da vulnerabilidade emocional de usuários jovens para promover publicidade em algumas ocasiōes. Esse episódio tornou-se emblemático de que há claramente uma linha tênue na questão ética quando se fala de algoritmos de análise de sentimento e políticas de proteção à privacidade. "Os computadores conectados, especialmente os celulares com seus inúmeros sensores, suscitam questôes éticas de toda natureza. A detecção de emoções de uma pessoa é mais uma pois representa uma forte invasão da privacidade caso ocorra sem o consentimento do indivíduo. Trata-se de um nível mais elaborado e profundo de coleta de informações do usuário, já que extrapola o que ele pretende expressar usando apenas palavras. Tentar inferir os sentimentos de alguém só pode ser feito com explícito consentimento e para fins muito bem definidos", alerta Rodrigues.

Casos de mau uso de dados de usuários de internet não são raros e podem se tornar cada vez mais frequentes se os devidos cuidados não forem tomados. O principal é colocar a questão em pauta e exigir políticas que garantam cada vez mais a proteção à privacidade dos usuários. Igualmente essencial é se conscientizar da importância de ler os contratos de uso antes de instalar qualquer aplicativo ou software - e de exigir que esses contratos sejam compreensíveis, para saber realmente com o que se está concordando.

\title{
HISTÓRIA DA ARTE TÉCNICA
}

\section{ESTUDOS INTERDISCIPLINARES}

AMPLIAM CONHECIMENTO SOBRE
CHINESICE NO BARROCO MINEIRO

Seda, madeiras aromáticas e têxteis, obras de arte, lã, cristais e muitas, muitas peças de porcelana chegaram ao Brasil ao longo dos séculos XVII e XVIII. A opulência proporcionada pelo ouro fez com que esses itens fossem ainda mais presentes em cidades mineiras como Ouro Preto, Mariana e Sabará. Esses objetos inspiraram a criação das chamadas chinesices, termo que designa um tipo de arte que evoca motivos chineses, presentes em várias igrejas barrocas de Minas Gerais. Mais recentemente, pesquisas no campo da história da arte técnica, área emergente que reúne métodos de investigação da história da arte, das análises físico-químicas e da ciência da conservação aplicados aos objetos artísticos culturais, têm possibilitado ampliar o conhecimento sobre a chinesice ou chinoiserie.

A presença de elementos de inspiração oriental no barroco mineiro não é novidade. O historiador e crítico de arte José Roberto Teixeira Leite fez um longo estudo sobre a influência da cultura chinesa no Brasil que resultou no livro A China no Brasil: influências, marcas, ecos e sobrevivências chinesas na sociedade e na arte brasileiras (Editora da Unicamp, 1999). Para celebrar essa influência, o fotógrafo mineiro Eduardo Tropia criou 13 telas utilizando a técnica de so- breposição de imagens para mostrar o embate entre a China e o barroco em pinturas encontradas em algumas igrejas de Ouro Preto.

MADE IN EUROPA A chinesice não é uma invenção asiática e sim europeia. "Não se trata de arte chinesa, mas sim de arte achinesada, arte de aparência, não de essência", escreveu Teixeira Leite. Segundo ele, é um modismo que surgiu na França na década de 1720 a partir de um encantamento com as artes do Oriente. Essa moda se espalhou por outros países como Inglaterra e Portugal, via pela qual a chinesice chegou ao Brasil. Aqui elas são fruto do desejo de uma sociedade ávida por adotar hábitos e costumes europeus. Ao serem adotadas nas igrejas barrocas e no mobiliário dos ricos as chinesices têm função estética, mas também de expressar uma sintonia com os padrōes em voga na Europa. "Ao abrirem o caminho para as Îndias os portugueses fizeram a Europa conhecer a China, que se tornou uma espécie de país dos sonhos", conta Luiz Antonio Cruz Souza, químico do Laboratório de Ciências da Conservação (Lacicor) da Universidade Federal de Minas Gerais (UFMG). No Brasil é bem provável que a inspiração para as pinturas nas igrejas 
